\title{
Determination of iron in urine with special reference to the desferrioxamine test
}

\author{
O. LUNDVALL AND A. WEINFELD \\ From First Medical Service, Sahlgren Hospital, University of Göteborg, Göteborg, Sweden
}

SYNOPSIS A simple and rapid method for the determination of ferrioxamine iron in urine, in which the colour reagent is added directly to centrifuged urine after reduction with dithionite, has been critically evaluated and compared with a method of iron determination after wet ashing. The coefficient of variation of both methods was less than $5 \%$. A very high correlation was found between the values obtained with the two methods, but the simple method gave consistently lower values, averaging about $85 \%$ of those by the wet ashing method. Iron present in the urine sediment or bound in a soluble form which is not split off by dithionite will not be measured with the simple method.

Despite its lower values the simple method gives uniform and reliable results, and is considered suitable for the performance of the desferrioxamine test.

In recent years the urinary iron excretion induced by desferrioxamine has been studied by several workers and found valuable for the estimation of iron stores and for the diagnosis of iron storage diseases (Wöhler, 1964; Ploem, 1965; Hallberg, Hedenberg, and Weinfeld, 1966).

Most workers have determined urinary iron spectrophotometrically after wet ashing (Wöhler, 1964; Walsh, Mass, Smith, and Lange, 1964; Hwang and Brown, 1964). These methods give reliable results but are time-consuming. Others (Hallberg and Hedenberg, 1965; Ploem, 1965), have used a simplified method without wet ashing (Keberle, 1964), in which the iron reagent is added directly to the urine after reduction of the ferrioxamine iron with dithionite. The aim of this study was to determine whether this simplified method gives results comparable with those obtained after wet ashing.

It has been reported (Wöhler, 1964) that $25 \%$ of the excreted iron may be found in the sediment. Since the simplified method requires centrifugation or filtration of the urine before analysis, the iron content of the urinary sediment and the effect of acidification of the urine during collection were also studied.

\section{METHODS}

All glassware and other utensils were carefully cleaned with hydrochloric acid and thoroughly rinsed with ironfree water. All reagents used were of analytical purity.

Received for publication 25 January 1967.
The urines analysed were collected in iron-free polythylene bottles for 24 hours after the intramuscular administration of $10 \mathrm{mg}$. desferrioxamine per kilogram body weight.

METHOD A This method is based on that of Keberle (1964). The iron is reduced and released from ferrioxamine with sodium hydrosulphite (dithionite). The iron is determined spectrophotometrically after the addition of $\alpha, a$-dipyridyl.

\section{Reagents}

Sodium hydrosulphite (dithionite) powder

Sulphuric acid, 0.05 N.

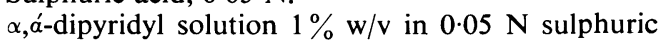
acid.

Phosphate buffer $1 / 15 \mathrm{M}, p \mathrm{H} 7$, according to Sörensen.

Standards These are 5, 10, 20, 40, 60, and $80 \mu \mathrm{g}$. iron $/ 20 \mathrm{ml}$. as solutions of ferrous ammonium sulphate in iron-free water.

Procedure Centrifuge the urine. Pipette $20 \mathrm{ml}$. of urine into a $50-\mathrm{ml}$. volumetric flask. Add $20 \mathrm{ml}$. of phosphate buffer solution and about $50 \mathrm{mg}$. of dithionite. Add iron-free water to the $50 \mathrm{ml}$. mark. Mix thoroughly Take $10 \mathrm{ml}$. aliquots of the solution into each of two tubes. Add to one tube $0.2 \mathrm{ml}$. of the $\alpha$, á-dipyridyl solution and to the other $0.2 \mathrm{ml}$. of $0.05 \mathrm{~N}$ sulphuric acid (urine blank). A reagent blank is prepared in the same way. Allow to stand for at least 30 minutes. Read the colour against water in either a spectrophotometer at $510 \mathrm{~m} \mu$ or in a suitable filter photometer ${ }^{1}$. According to the intensity of the colour developed a 10 or $40 \mathrm{~mm}$. cell is used. The optical density (O.D.) of the reagent blank and urine blank is subtracted from that of the sample ${ }^{1}$ The authors used an Eppendorf photometer with filter No. 492, photocell No. 90B and a mercury lamp. 
examined. The iron content of the sample is obtained by reading the corrected O.D. from a calibration curve plotted from standard iron solutions taken through in exactly the same way as urine samples. One calibration curve was prepared for the $40 \mathrm{~mm}$. cell from standards of 5 to $40 \mu \mathrm{g}$.per $20 \mathrm{ml}$., and another was prepared for the $10 \mathrm{~mm}$. cell (for urines containing large quantities of iron) from standards of 20 to $80 \mu \mathrm{g}$. per $20 \mathrm{ml}$. The calibration curves are linear within the ranges specified. One standard iron solution containing $20 \mu \mathrm{g}$. per $20 \mathrm{ml}$. was run in triplicate with each batch of analyses. The variation of the O.D. of the iron standards on different days was negligible.

All iron determinations were performed in duplicate. The standard deviation of a single determination calculated from 58 random duplicate determinations over a range of 0 to $41.6 \mu \mathrm{g} . / 20 \mathrm{ml}$. was $\pm 0.49 \mu \mathrm{g} . / 20 \mathrm{ml}$, which corresponds to a coefficient of variation of $3.9 \%$ (Table I).

\section{TABLE I}

ANALYTICAL ERROR OF IRON DETERMINATION IN URINE BY METHOD $A^{1}$

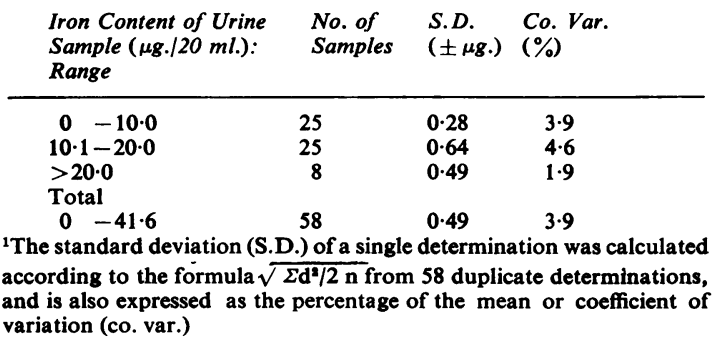

In recovery experiments known amounts of iron (ferrous ammonium sulphate) were added to three different urines. The results are given in Table II. The mean recovery was $94 \%$ and ranged from 84 to $104 \%$.

\section{TABLE II}

RECOVERY OF IRON ADDED TO URINES FROM THREE SUBJECTS BY METHOD A

\begin{tabular}{ccc}
$\begin{array}{l}\text { Fe Originally Present } \\
\text { in } 20 \mathrm{ml} \text {. of Urine ( } \mu \mathrm{g} .)\end{array}$ & $\begin{array}{l}\text { Fe Added } \\
(\mu \mathrm{g} .)\end{array}$ & $\begin{array}{l}\text { Added FeRecovered } \\
(\mu \mathrm{g} .)\end{array}$ \\
\hline 0 & 5 & $4.2(84 \%)$ \\
& 10 & $9 \cdot 2(92 \%)$ \\
0 & 40 & $38.8(97 \%)$ \\
& 5 & $4.4(87 \%)$ \\
& 10 & $10 \cdot 4(104 \%$ mean $94 \%)$ \\
$61 x$ & 20 & $19.6(98 \%)$ \\
& 40 & $40.4(101 \%)$ \\
& 20 & $18.0(90 \%)$ \\
& 80 & $76.8(96 \%)$ \\
The figures are means of duplicate determinations.
\end{tabular}

When the $p \mathrm{H}$ of the urine is below 5.5 the dithionite may precipitate, and cloudy samples are not suitable for analysis. In alkaline urine, however, ferrioxamine is reduced too slowly. Therefore urines which are strongly acid, naturally or from the additions of acid during collection, must be으 brought near to neutrality before dithionite is added. In order to simplify the procedure $1 / 15$ molar phos- $-\stackrel{5}{?}$ phate buffer of $p \mathrm{H} 7$ was added to the sample; this ensured a suitable $p \mathrm{H}$ for analysis even when the urine was collected in bottles containing $5 \mathrm{ml}$. of $3 \mathrm{~N}$ hydrochloric acid. The analysis of standard $\mathbb{Q}$ iron solutions of ferrous ammonium sulphate or ferrioxamine solutions was not influenced by theaddition of phosphate buffer. The colour was fully: developed after 15 minutes.

METHOD B The iron content of urine is measured spectrophotometrically with o-phenanthroline after wet? ashing.

\section{Reagents}

Nitric acid, concentrated

Sulphuric acid, concentrated and $5 \mathrm{~N}$

Hydrochloric acid, $5 \mathrm{~N}$

p-Nitrophenol, $1 \% \mathrm{w} / \mathrm{v}$ in ethanol

Ammonia, concentrated

Hydroquinone, $2 \%$

o-Phenanthroline, $1 \%$

Standards These were 2, 4, 8, 10, 40, and $80 \mu \mathrm{g} . \%$ iron $/ 20 \mathrm{ml}$. as solutions of ferrous ammonium sulphate in iron-free water.

Procedure Place $20 \mathrm{ml}$. of urine into a $250 \mathrm{ml}$. Erlenmeyer flask. Add $5 \mathrm{ml}$. of concentrated nitric acid. Evaporate on a hot plate to about $10 \mathrm{ml}$. with glass beadsa to prevent bumping. Transfer the solution quantitativelyo to a $50 \mathrm{ml}$. Kjeldahl flask. Pipette $2 \mathrm{ml}$. of concentrated nitric acid into the Erlenmeyer flask, boil until it refluxeso and transfer the liquid quantitatively to the Kjeldahl flask with three rinses of about $2 \mathrm{ml}$. of iron-free water Evaporate the content of the Kjeldahl flask to about $5 \mathrm{ml}$, and add $2 \mathrm{ml}$. of concentrated sulphuric acid Digest until a colourless solution remains. Repeat the digestion if necessary by adding $0.5 \mathrm{ml}$. of concentrated? nitric acid drop by drop. (The maximal amount of nitrie acid required for any one sample is added to all samplesô and to the reagent blank and standards which are ashece in the same way.) When the solution is clear, boil untib all the nitric oxides have been expelled. Cool partially? and add $1.5 \mathrm{ml}$. of iron-free water and $2 \mathrm{ml}$. of $5 \mathrm{~N}$ hydro $=0$ chloric acid. Heat until white fumes appear and then cool. Add iron-free water to a volume of about $10 \mathrm{ml} / \mathrm{N}$ After the addition of water, calcium sulphate precipitates Leave standing for two hours or overnight. Filter into aO $25 \mathrm{ml}$. volumetric flask. Rinse the Kjeldahl flask threew times with about $2 \mathrm{ml}$. of iron-free water and add the wash to the volumetric flask through the filter. Neutralize with concentrated ammonia using 2 drops of p-nitro $\frac{-}{0}$ phenol as indicator. Add $5 \mathrm{~N}$ sulphuric acid, drop byes drop until the green colour disappears again $(p \mathrm{H} 2 \cdot 5-3 \cdot 0)$ Add $1.5 \mathrm{ml}$. of $2 \%$ hydroquinone solution and $0.5 \mathrm{ml}$ of $1 \%$ o-phenanthroline solution. Leave standing over night. Fill with iron-free water to the $25 \mathrm{ml}$. mark. Mix thoroughly. Read the colour against water in a spectro 20 photometer at $510 \mathrm{~m} \mu$ or in a suitable filter photometer. ${ }^{1}$ The authors used the Eppendorf photometer as in method $\mathrm{A}$. 
The O.D. of the reagent blank is subtracted from that of the sample examined. The corrected O.D. is read from a calibration curve from standard iron solutions taken through in exactly the same way as the urine samples. The calibration curve for the $40 \mathrm{~mm}$. cell was prepared from standards of 2 to $8 \mu \mathrm{g}$. per $20 \mathrm{ml}$., while that for the $10 \mathrm{~mm}$. cell was prepared from standards of 10 to $80 \mu \mathrm{g}$. per $20 \mathrm{ml}$. The calibration curves are linear within the ranges specified. One standard iron solution of $8 \mu \mathrm{g}$. iron per $20 \mathrm{ml}$. was run in triplicate with each batch of analyses. If any of the urines analysed was expected to have increased iron concentration a triplicate standard solution of $40 \mu \mathrm{g}$. was included.

The error of the method was calculated from 71 random duplicate determinations on urines containing 0-63.8 $\mu \mathrm{g}$. of iron $/ 20 \mathrm{ml}$. The standard deviation of a single determination was $\pm 0.66 \mu \mathrm{g} . / 20 \mathrm{ml}$. of urine, corresponding to a coefficient of variation of $3.9 \%$ (Table III).

Recovery experiments, shown in Table IV, averaged $99 \%$ with a range of 94 to $102 \%$.

\section{TABLE III}

ANALYTICAL ERROR OF IRON DETERMINATION IN URINE BY METHOD B ${ }^{1}$

\begin{tabular}{llll}
$\begin{array}{l}\text { Iron Content of Urine } \\
\text { Sample }(\mu \mathrm{g} .120 \mathrm{ml} .):\end{array}$ & $\begin{array}{l}\text { No. of } \\
\text { Samples }\end{array}$ & $\begin{array}{l}\text { S.D. } \\
( \pm \mu \mathrm{g} .)\end{array}$ & $\begin{array}{l}\text { Co. Var. } \\
(\%)\end{array}$ \\
\hline $\begin{array}{llll}\text { Range } \\
10.1-20.0\end{array}$ & 28 & 0.50 & 7.7 \\
$>20.0$ & 25 & 0.64 & 4.2 \\
Total & 18 & 0.89 & 2.5 \\
$0-63.8$ & 71 & 0.66 & 3.9
\end{tabular}

${ }^{1}$ The standard deviation (S.D.) of a single determination was calculated according to the formula $\sqrt{\Sigma \mathrm{d}^{2} / 2} \mathrm{n}$ from 71 duplicate determinations, and is also expressed as the percentage of the mean or coefficient of variation (co. var.)

\section{RESULTS}

COMPARISON OF IRON DETERMINATIONS IN URINE BY METHODS A AND B The results are shown in Table V.

Acidified urine Aliquots of $20 \mathrm{ml}$. for analysis by method B were drawn from mixed urine before centrifugation and similar aliquots for analysis according to method $\mathbf{A}$ were drawn after centrifugation from 63 urines collected in bottles containing
TABLE IV

RECOVERY OF IRON ADDED TO URINE COLLECTED AFTER ADMINISTRATION OF DESFERRIOXAMINE BY METHOD $\mathbf{B}^{1}$

\begin{tabular}{ccl}
$\begin{array}{l}\text { Fe Originally Present } \\
\text { in } 20 \text { ml. of Urine } \\
(\mu \mathrm{g})\end{array}$ & $\begin{array}{l}\text { Fe Added } \\
(\mu \mathrm{g} .)\end{array}$ & $\begin{array}{l}\text { Added Fe } \\
\text { Recovered } \\
(\mu \mathrm{gg})\end{array}$ \\
\hline 13.5 & 10 & $10.0(100 \%)$ \\
& 20 & $20.0(100 \%) \mathrm{Mean}$ \\
& 40 & $37.6(94 \%) 99 \%$ \\
& 80 & $81.6(102 \%)$
\end{tabular}

$5 \mathrm{ml}$. of $3 \mathrm{~N}$ hydrochloric acid. The results are shown in Fig. 1 and in Table V. Slightly but consistently lower values were obtained with method $\mathbf{A}$ which averaged $87.6 \%$ of the mean value obtained with method B. There was, however, a very high correlation between the two methods with a correlation coefficient of 0.99 . The equation of linear regression of method A upon method $B$ was $y_{x}=0.93 x-1.0$.

NON-ACIDIFIED URINE Aliquots were drawn in the same manner as above from 38 urines collected in bottles without acid. The results are given in Table V. Consistently lower values were obtained with method A averaging $81.3 \%$ of the mean value obtained with method B. The correlation coefficient was 0.99 and the equation of linear regression of method $A$ upon method B was $y_{x}=0.89 x-1.2$. This regression line is not significantly different from that given by acidified urines.

CENTRIFUGED URINE Analyses by both methods were performed on aliquots drawn from 45 centrifuged urines. The results are given in Table V. Method A again gave consistently lower values than method $B$ averaging $86.9 \%$ of the mean value obtained with method B. The correlation between the two methods was very high with a correlation coefficient of 0.99 . The equation of linear regression was $\mathrm{y}_{x}=0.90 x-$ $0 \cdot 5$. There was no significant difference between this regression line and those obtained in the preceding experiments.

IRON CONTENT OF THE URINE SEDIMENT Direct and indirect determinations were made.

TABLE $\mathrm{V}$

URINARY IRON BY METHOD A (WITH CENTRIFUGATION OF URINE) AND METHOD B (WITH AND WITHOUT CENTRIFUGATION)

\begin{tabular}{|c|c|c|}
\hline \multicolumn{2}{|c|}{$\begin{array}{l}\text { Method A (after Centrifugation) } \\
\text { Method B (before Centrifugation) }\end{array}$} & \multirow[t]{2}{*}{$\begin{array}{l}\text { Method A (a) } \\
\text { Method B (a) }\end{array}$} \\
\hline Acidified Urine & Non-acidified Urine & \\
\hline $\begin{array}{l}63 \\
15.9 \pm 12.3 \\
18.2 \pm 13.1 \\
2.3 \pm 0.2 \\
P<0.001\end{array}$ & $\begin{array}{l}38 \\
12.1 \pm 10.1 \\
15.0 \pm 11.3 \\
2.8 \pm 0.3 \\
P<0.001\end{array}$ & $\begin{array}{l}45 \\
13.5 \pm 10.4 \\
15.5 \pm 11 \cdot 3 \\
2.0 \pm 0.3 \\
P<0.001\end{array}$ \\
\hline
\end{tabular}

Number of urines analysed

Method A: mean \pm S.D. ( $\mu \mathrm{g} . / 20 \mathrm{ml}$.)

Method B: mean \pm S.D. ( $\mu \mathrm{g} . / 20 \mathrm{ml}$.)

Difference $(B-A):$ mean \pm S.E. $(\mu \mathrm{g} . / 20 \mathrm{ml}$.)

Level of significance
$2 \cdot 3 \pm 0.2$

$\mathbf{P}<0.001$ 


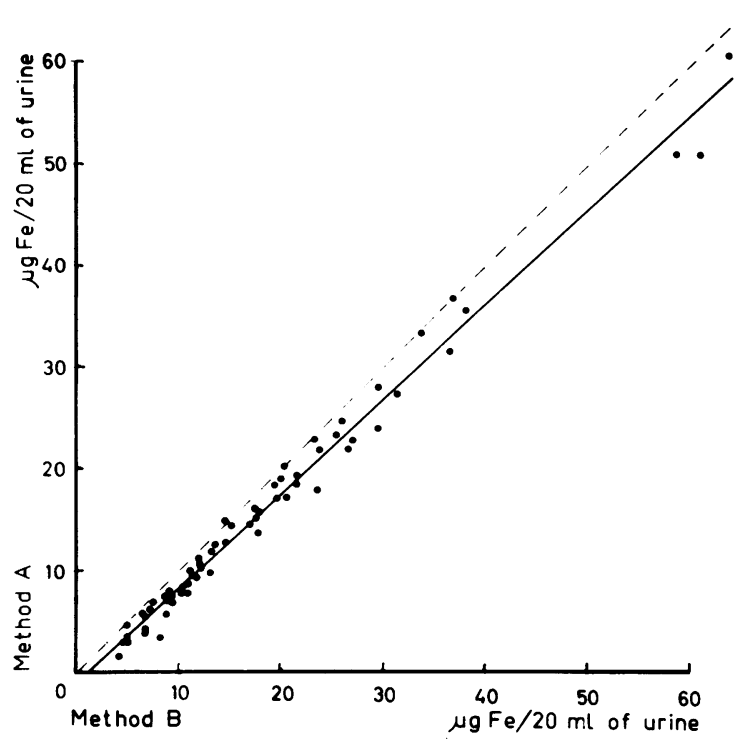

FIG. 1. Comparison between simple method $A$ and wet ashing method $B$ using acidified urine. Aliquots for analysis by method $B$ were drawn from mixed urine before centrifugation and for analysis by method $A$ after centrifugation. The correlation coefficient was 0.99 and the equation of linear regression of method $A$ upon method $B$ was $y_{x}=$ $0.93 x-1.0$.

The dotted line represents equal values by both methods.

DIRECT DETERMINATIONS OF IRON IN URINE SEDIMENT The urines obtained from seven subjects were collected in bottles without acid. After having been vigorously shaken each urine was divided into two equal parts. To one part hydrochloric acid was added. The urines were then stored for four to seven days before analysis. Iron determination was performed on the sediment and supernatant by the wet ashing method.

The results are given in Table VI. The total iron content of the urines ranged from 0.78 to $17.2 \mathrm{mg}$. The iron content of the urine sediments ranged from 0.01 to $0.09 \mathrm{mg}$. and was independent of the total iron content; thus when expressed as a per=centage of the total iron of the urine it range widely from 0.3 to 7.2 (mean 2.5 ) in unacidifieg urine and from 0.6 to 6.3 (mean 2.7 ) in acidifief urine.

INDIRECT DETERMINATION OF IRON IN THE URINE SEDIMENT Iron was determined before and afters centrifugation of the urine by the wet ashings method; 10 urine portions were acidified with hydro chloric acid and 11 were not acidified. The urines werg్ stored for four to seven days before analysis. Afte vigorously shaking aliquots were taken with and with? out centrifugation for analysis by the wet ashing method.

The results are given in Table VII. There was n difference in the mean iron content of the urines before and after centrifugation when the urine had been supplied with hydrochloric acid. In unacidified urine the mean iron content was $2 \%$ lower aftef centrifugation.

\section{TABLE VII}

IRON CONTENT PER 24 HR. IN URINE OF ACIDIFIED AND NON-ACIDIFIED URINES BEFORE AND AFTER CENTRIFUGATION ESTIMATED BY THE WET ASHING METHOD B

\begin{tabular}{|c|c|c|}
\hline & Acidified Urine & $\begin{array}{l}\text { Non-acidified } \\
\text { Urine }\end{array}$ \\
\hline $\begin{array}{l}\text { Number of urines analysed } \\
\text { Before centrifugation: }\end{array}$ & $\begin{array}{l}10 \\
21 \cdot 4 \pm 17 \cdot 1\end{array}$ & $\begin{array}{l}11 \\
20 \cdot 5 \pm 16 \cdot 7\end{array}$ \\
\hline $\begin{array}{l}\text { After centrifugation: } \\
\text { mean }+ \text { S.D. }(\mu \mathrm{g} . / 20 \mathrm{ml}) \text {. }\end{array}$ & $21 \cdot 4 \pm 17 \cdot 5$ & $20 \cdot 1 \pm 17 \cdot 1$ \\
\hline $\begin{array}{l}\text { Mean difference } \pm \text { S.E. } \\
(\mu \mathrm{g} . / 20 \mathrm{ml} .) \\
\text { Level of significance }\end{array}$ & $\begin{array}{l}0.0 \pm 0.3 \\
P>0.10\end{array}$ & $\begin{array}{l}00.4 \pm 0.2 \\
P<0.1,>0.05\end{array}$ \\
\hline
\end{tabular}

DISCUSSION

Determination of ferrioxamine iron in urine using the method described by Keberle is simple and does

TABLE VI

IRON CONTENT OF URINE SEDIMENT AND ITS ITS RELATION TO TOTAL IRON CONTENT OF URINE AS DETERMINED BY THE WET ASHING METHOD (B)

\begin{tabular}{|c|c|c|c|c|c|c|}
\hline \multirow{3}{*}{ Urine No. } & \multicolumn{3}{|l|}{ Acidified Urine } & \multicolumn{3}{|l|}{ Non-acidified Urine } \\
\hline & \multirow{2}{*}{$\begin{array}{l}\text { Total Iron Content } \\
\text { of 24-Hour Urine } \\
\text { (mg.) }\end{array}$} & \multicolumn{2}{|c|}{$\begin{array}{l}\text { Iron Content in the } \\
\text { Sediment of 24-Hour Urine }\end{array}$} & \multirow[t]{2}{*}{$\begin{array}{l}\text { Total Iron Content } \\
\text { of 24-Hour Urine (mg.) }\end{array}$} & \multicolumn{2}{|c|}{$\begin{array}{l}\text { Iron Content in the } \\
\text { Sediment of } 24-\text { Hour Urine }\end{array}$} \\
\hline & & mg. & $\%$ of Total Iron & & $m g$. & $\%$ of Total Iron \\
\hline $\begin{array}{l}1 \\
2 \\
3 \\
4 \\
5 \\
6 \\
7 \\
\text { Mean }\end{array}$ & $\begin{array}{l}1 \cdot 59 \\
16 \cdot 3 \\
4 \cdot 72 \\
1 \cdot 40 \\
13 \cdot 4 \\
0 \cdot 79 \\
0.83\end{array}$ & $\begin{array}{l}0.06 \\
0.09 \\
0.05 \\
0.01 \\
0.07 \\
0.05 \\
0.05 \\
0.05\end{array}$ & $\begin{array}{l}3.8 \\
0.6 \\
1.1 \\
0.7 \\
0.5 \\
6.3 \\
6.0 \\
2.7\end{array}$ & $\begin{array}{c}1 \cdot 65 \\
17 \cdot 2 \\
4.87 \\
1.44 \\
13.6 \\
0.83 \\
0.78\end{array}$ & $\begin{array}{l}0.04 \\
0.06 \\
0.06 \\
0.01 \\
0.05 \\
0.06 \\
0.04 \\
0.05\end{array}$ & $\begin{array}{l}2 \cdot 4 \\
0 \cdot 3 \\
1 \cdot 2 \\
0 \cdot 7 \\
0 \cdot 4 \\
7 \cdot 2 \\
5 \cdot 1 \\
2 \cdot 5\end{array}$ \\
\hline
\end{tabular}


not require the laborious procedure of wet ashing. The addition of phosphate buffer to the urine sample prevents precipitation of dithionite even when the urine has been moderately acidified during collection, and no correction of $p \mathrm{H}$ is necessary for the colour development. With this modification the method proved to have a coefficient of variation of $3.9 \%$. Comparison of this method with the wet ashing method showed a very high correlation. The simplified procedure gave consistently lower values but the absolute difference was small (about $15 \%$ ). The lower values obtained with the simplified method are not explicable by loss of iron through centrifugation, because the same difference was found when centrifuged urine was used for both methods. Apparently there is a fraction of complex-bound iron in urine, which is not split off and available for the colour reaction when dithionite is added. This, however, does not invalidate the simplified method since the results obtained correlate well with those of the wet ashing method.

It has been reported (Wöhler, 1964) that precipitation of iron may occur in non-acidified urine and that as much as $25 \%$ of the amount excreted may be found in the urine sediment. If considerable and varying amounts of iron are found in the sediment the simplified method would give unreliable results, since this analysis is performed on centrifuged or filtered urine. The results of the present study, however, show that only small quantities of iron, averaging $0.05 \mathrm{mg}$. $/ 24 \mathrm{hr}$., are present in the sediment and are not proportional to the total iron content of the urine. Hence the percentage of iron in the sediment is negligible unless the total iron content is small (Table VI).

The experiment to define the significance of acidifying the urine gave somewhat conflicting results. Direct analyses of the urine sediment were not influenced by acidification (Table VI). However, whereas analyses of acidified urine by the wet ashing method did not reveal any difference in the iron content whether the urine was centrifuged or not, similar analyses of non-acidified urine showed the mean concentration of iron to be an average $2 \%$ lower in centrifuged than in uncentrifuged samples, a difference of about $0.4 \mu \mathrm{g} . / 20 \mathrm{ml}$. (Table VII); however, this difference does not quite reach the conventional level of significance. Similarly the difference between the values obtained with the wet ashing method (before centrifugation) and the simplified method (after centrifugation of the urine) was greater in non-acidified urine than in acidified urine, but not significantly so (Table V). Thus in the present study acidification of the urine was found to be relatively unimportant. However, the addition of $5 \mathrm{ml}$. $3 \mathrm{~N}$ hydrochloric acid to urine-collecting bottles is recommended as a simple precaution that may be of importance, especially when the urine is alkaline and the sediment is heavy.

This work was supported by the Swedish Medical Research Council (project no. 25x-593-2).

\section{REFERENCES}

Hallberg, L., and Hedenberg, L. (1965). Scand. J. Haemat., 2, 67. and Weinfeld, A. (1966). Ibid., 3, 85.

Hwang, Y.-F., and Brown, E. B. (1964). Arch. intern. Med., 114, 741.

Keberle, H. (1964). A simple and rapid method for the assay of iron in the urine after the administration of desferrioxamine. Communication from the research laboratories, CIBA limited, Basle.

Ploem, J. E. (1965). Diagnostische proef voor ijzer-stapeling bij de mens. Van Gorcum, Utrecht.

Walsh, J. R., Mass, R. E., Smith, F. W., and Lange, V. (1964). Arch. intern. Med., 113, 435.

Wöhler, F. (1964). Acta haemat. (Basel), 32, 321. 